Department of Anesthesia, Cardiology and Endoscopy. National Cancer Institute "G. Pascale" Foundation, Naples,

Received March 19, 2015.

Conflicts of interest: none to declare.

Correspondence to:

Prof. Dr. Marco Cascella Via Mariano Semmola, 80131 Naples, Italy. Phone-Fax: 00390815903778 m.cascella@istitutotumori.na.it

\section{Maria Montessori (1870-1952). Women's emancipation, pedagogy and extra verbal communication}

\author{
MARCO CASCELLA
}

\begin{abstract}
Maria Montessori is one of the most well-known women in Italian history. Although she was the first woman who graduated in medicine in Italy, she is mostly known as an educator. Her teaching method -the Montessori Method-is still used worldwide. Because she could not speak English during the imprisonment in India, there was a big obstacle for her communication with children. However, the need to adopt a non-verbal communication, led her to a sensational discovery: children use an innate and universal language. This language, made of gestures and mimic, is called "extra verbal communication".
\end{abstract}

(Rev Med Chile 2015; 143: 658-662)

Key words: Dementia: Educational Techniques; Pedagogy; Educational Techniques; Nonverbal Communication.

\section{$\mathrm{M}$} aria Montessori is one of the most wellknown women in Italian history (Figure 1$)^{1}$. Although she was the first woman obtaining an MD title in Italy, she is mostly known as an educator and pedagogue: a true pioneer in children's education ${ }^{2}$.

Her teaching method -the eponymous "Montessori Method" - is still used by thousands of kindergartens, elementary, middle and high schools all over the world.

She was born August 31, 1870, in Chiaravalle, an Italian village in the Ancona province, but spent her youth in Rome. She attended the elementary school without remarkable results, due to health problems. Growing up, she showed a particular inclination for scientific topics. Despite many obstacles, she enrolled in the Faculty of Medicine at the Sapienza University of Rome. During an interview with The Globe, she would later declare that she asked for help from Pope Leone XIII to enter the Faculty. Thanks to her stubbornness, she became the first Italian woman to graduate in medicine, in 1896. During the university years, she focused her studies and research on paediatrics, psychiatry and hygiene, subjects on which she proved her interest even later.

After graduating, she became assistant in the psychiatric clinic at the University of Rome, taking care of children with mental problems. During this period of time she attended medical conferences and meetings in Europe. Montessori had the chance to know and deepen her knowledge on methods and theories about the recovery of "abnormal children" as they were called at the time.

By reading the works of the French pedagogue Jean Marc Gaspard Itard (1774-1838) $)^{3,4}$ and his collaborator Edouard Seguin (1812-1880) $)^{5}$, both considered the fathers of social pedagogy, she began to study the possibility for inserting these "abnormal" children back to the community, through an adequate educational path, until she reached the conclusion that the treatment for these children should have been pedagogical, in addition to medical.

In this period Montessori contributed to women's emancipation. She joined the Women's Congress of Berlin in 1896 as a representative of Italy, delivering a famous speech on the right to 
equal pay for women and men. She also participated in the following Women's Congress of London $(1899)^{6}$.

\section{Children's House in Rome}

A first chance to put these ideas into practice was offered to her in 1904, when she obtained a teaching position in anthropology, and thus the opportunity to be involved in the management of educational programs for kindergartens. She soon developed a teaching method that could fit for children between three and six years old, and applied it in the poor neighbourhood of San Lorenzo, in Rome, where she founded the first "Casa dei Bambini" (Children's House) in 1907

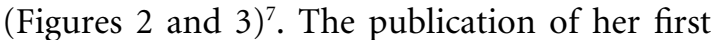
book, "Il Metodo della Pedagogia Scientifica" (Dr. Montessori's Own Handbook), dates back to these years ${ }^{8}$. The text reports the ideas that she developed during her first years of work in the Children's House and was met with enthusiasm worldwide. On her arrival in the United States, in 1913, the New York Tribune regarded her as "the most interesting woman in Europe". Her teaching method was translated into 22 languages and was used in 17 different nations. This experiment was repeated in every continent and schools following

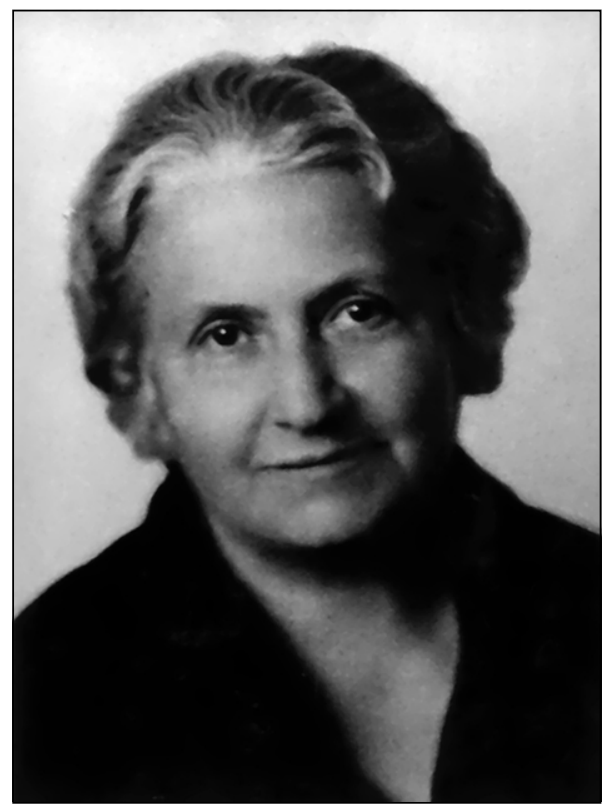

Figure 1. Maria Montessori: portrait. her method were built almost everywhere. At present there are about 22,000 Montessori schools of every grade worldwide.

\section{The Montessori Method}

The Montessori educational method ${ }^{9}$ is based on two principles: the non-interference with the

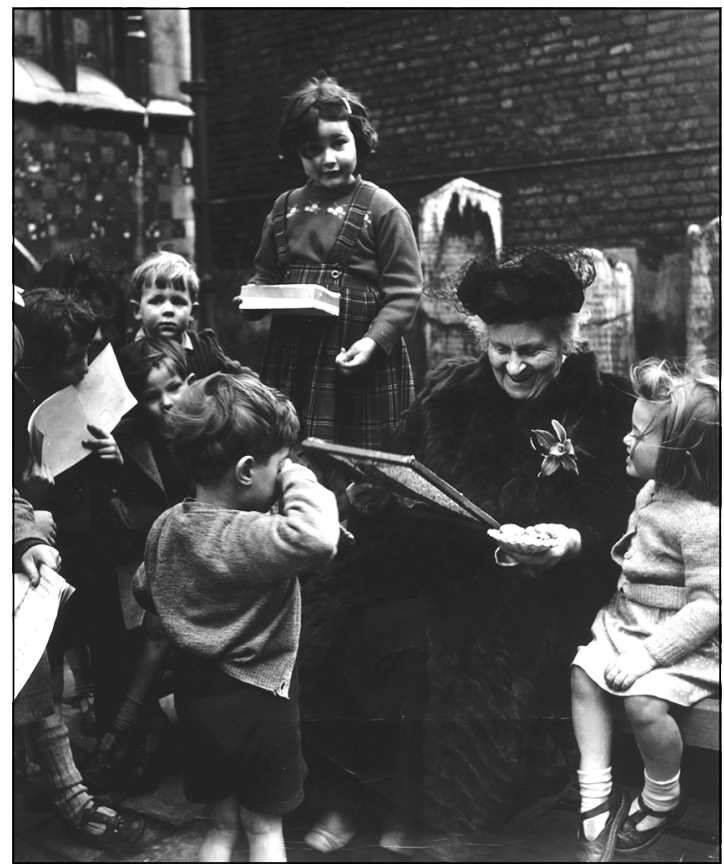

Figure 2. Maria Montessori in Children's House (Rome, Italy).

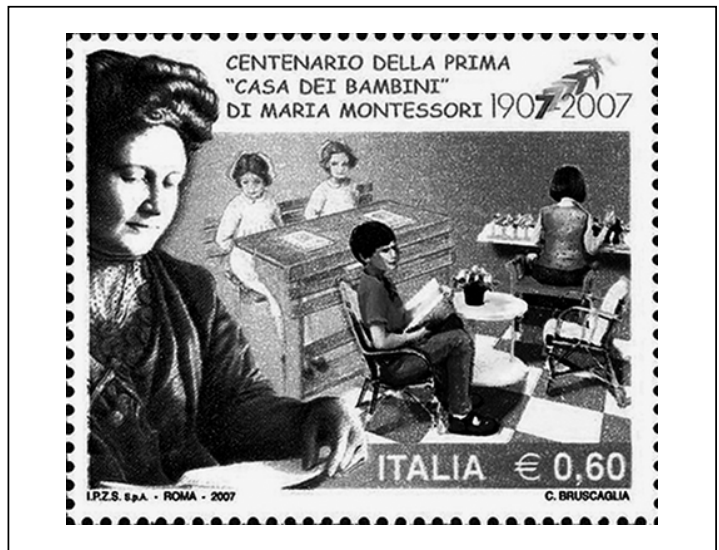

Figure 3. Maria Montessori. Centenary of the first Children's House. Stamp. Italy (2007). 
individuality and expressive freedom of the child, and the use of a specific sensorial training on the early stages of development. The method is characterized by an emphasis on independence, freedom within limits, and respect for a child's natural psychological, physical, and social development. Although a range of practices exists under the name "Montessori", the Association Montessori Internationale (AMI) and the American Montessori Society (AMS) cite these elements as essential: mixed age classrooms (with classrooms for children aged 21/2 or 3 to 6 years old are by far the most common), student's choice of activity within a prescribed range of options, uninterrupted blocks of work time (ideally three hours), a constructivist or "discovery" model, where students learn concepts from working with materials, rather than by direct instruction, specialized educational materials developed by Montessori and her collaborators, freedom of movement within the classroom. It is mandatory the presence of a trained Montessori teacher in each class.

\section{The Montessori Method applied in people with dementia}

Because some researchers have thought to apply the Montessori Method to adults it has also been used in people with dementia ${ }^{10}$, specially to maintain patient's self-feeding ability ${ }^{11}$ or to reduce agitation and aggressive behaviors ${ }^{12}$. Cameron J Camp ${ }^{13}$, studying the validity of both implicit and procedural learning systems of the Montessori method, proposed to exploit the linkages between Montessori's approach and the translation of concepts in neuroscience into practical interventions for people with dementia ${ }^{14}$.

While the real efficacy of the method in this field of application has yet to be established ${ }^{15}$, these experiments show the genius and foresight of a great woman.

\section{Maria and the Fascism of Benito Mussolini}

Maria began working in a complex historical period. At first, she accepted the endorsement of Fascist dictator Benito Mussolini, who had showed interest in solving the problem of illiteracy through the Children's Houses, most probably to take personal advantage of Montessori's international fame in the process.
Maria might have hoped that Mussolini's approval could favour the spread of her movement in Italy. Indeed, during the first years of this regime, she didn't find any impediments on opening new schools in Italy or teaching her courses abroad.

However, the idea that children should not be forced in the rigid physical and mental patterns of the adults would soon find the hostility of the Fascist and Nazi elites, who preferred the belligerent conditioning of their respective youth movements (namely, the Italian Youth of the Lictor and the German Hitlerjugend). The order to close every Montessori school for children and adults was emanated by Mussolini for the Italians in 1934, and by Hitler, for schools in Germany and Austria, on the same year. In 1936, the Fascist regime closed all Montessori Method schools that were under the rule of the Kingdom of Italy.

In 1934, because of an irrecoverable contrast with the regime, she was forced to leave her own country. She kept travelling through Sweden, Spain, England and the Netherlands to spread her theories on education.

\section{Prisoner in India}

In 1939, she arrived in India but, soon after, Second World War broke out and she was taken prisoner by the British government and interned in a camp.

Despite that, as Montessori herself had admitted many times, her stay in India was "the most beautiful and incredible period of my life". This experience contributed a lot to the development of her theories and philosophy, especially with regards to the development of children's language. The British allowed her to carry on her work lecturing on the Montessori Method to Indian audiences, but the fact that the pedagogue could not speak English posed a big obstacle to her communication with children. However, this same obstacle, and the subsequent need to adopt a non-verbal communication, led her to a sensational discovery: children use an innate and universal language which is also particularly developed. Today, this language, made of gestures and mimic, is called "extra verbal communication"16-18. The continuous exchange of information with the external world makes the children receptive to every form of learning, aside from the acqui- 
sition of new languages. Maria Montessori confronted this discovery with her previous studies on children that, having lived in a socio-cultural isolation, had not been adequately stimulated in their education and that, once grown up, were showing inadequacies in expressing themselves, mostly together with cognitive and performance gaps at different levels.

The merit of her research was the understanding that the reason for this children's "muteness" and learning deficiencies was a poor or non-existent environmental stimulation, instead of inborn congenital defects.

Montessori's forced exile in India and her lack of language knowledge helped her to develop an extraordinary experimental model, thanks to which she could study the stages of development of psychomotricity in children and elaborate on the theory of an "Absorbent Mind", laying the foundations for modern educational psychology.

After the Second World War, she went back to Europe, where was welcomed with honours everywhere. Upon returning to Italy in 1947 she immediately worked on building back her activity to keep spreading her theories. She was nominated for the Nobel Prize for Peace in 1949, 1950 and $1951^{19}$.

She died on May 6, 1952, in the Dutch city of Noordwijk, where she was living. On her grave, in Italian, are inscribed these words: "Io prego $i$ cari bambini, che possono tutto, di unirsi a me per la costruzione della pace negli uomini e nel mondo" (I pray the dear children, who can all, to join me for the building of peace in men and the world).

Maria Montessori's biography helps us to trace the profile of a great woman, remarkably ahead of her time who, with passion and determination, turned her dream and the "discovery of children" into lifetime missions. Her educational method is still followed everywhere in the world ${ }^{20}$. Although over the years several changes to the method have been proposed, according to Lillard's studies classical Montessori programs compared with children in supplemented Montessori and conventional programs, can better promote the development of large motor ability, fine movements, language, and social behavior in children ${ }^{21}$.

Acknowledgement: This article was written in memory of my mother, who was a Montessori teacher for 40 years.

\section{References}

1. Babini VP, Lama L. Maria Montessori: a woman of science. Risorgimento 1999; 51 (2-3): 259-80.

2. Shampo MA, Kyle RA. Maria Montessori (1870-1952). JAMA 1976; 23; 235 (8): 815.

3. Itard JMG.De l'education d'un hommesauvageou des premiers developpemens physiques et moraux du jeunesauvage de l'Aveyron. Paris: Goujon, 1801.

4. Gineste T. La pensée médico-psychologique de JeanMarc Gaspard Itard. Bulletin de la Société d'histoire de la médecine 1989; 23 (2): 115-20.

5. Edouard Seguin published the Traitement Moral, Hygiène, et Education des Idiots (1846). This work is considered the first systematic textbook dedicated to the special needs of children with mental disabilities.

6. Standing EM. Maria Montessori, Her Life and Work. New York: Plume, 1984.

7. Foschi R. Science and Culture Around The Montessori's First “Children's Houses” in Rome (1907-1915). J Hist Behav Sci 2008; 44 (3): 238-57.

8. Montessori M. Il Metodo della Pedagogia Scientifica applicato all'educazione infantile nelle Case dei Bambini. Città di Castello: Lapi, 1909.

9. Montessori M. The Human Tendencies and Montessori Education. Amsterdam: Association Montessori International, 1966.

10. Vance DE, Porter RJ. Montessori methods yield cognitive gains in Alzheimer's day cares. Activities, Adaptation, and Aging 2000; 24: 1-22.

11. Lin LC, Huang YJ, Watson R, Wu SC, Lee YC. Using a Montessori method to increase eating ability for institutionalised residents with dementia: a crossover design. J Clin Nurs 2011; 20 (21-22): 3092-101.

12. Lin LC, Yang MH, Kao CC, Wu SC, Tang SH, Lin JG. Using acupressure and Montessori-based activities to decrease agitation for residents with dementia: a crossover trial. J Am Geriatr Soc 2009; 57 (6): 1022-9.

13. Camp CJ. Montessori-Based Dementia Programming ${ }^{\mathrm{TM}}$ in long-term care: A case study of disseminating an intervention for persons with dementia. In: Intrieri RC, Hyer L, editors. Clinical applied gerontological interventions in long-term care. New York: Springer; 2006. pp. 295-314.

14. Camp CJ. Origins of Montessori Programming for Dementia. Nonpharmacol Ther Dement 2010; 1 (2): 163-74.

15. Brandão DF, Martín JI. Montessori method applied to dementia-literature review. Rev Gaucha Enferm 2012; 33 (2): 197-204.

16. Stokoe WC. Sign language structure: an outline of the visual communication systems of the American Deaf. Studies in Linguistics, Occasional Papers. 1960; 8. 
17. Graham JA, Argyle M. A Cross-Cultural Study of the Communication of Extra-Verbal Meaning by Gesture. International Journal of Psychology 1975; 10 (1): 57 67.

18. Pouw WT, de Nooijer JA, van Gog T, Zwaan RA, Paas F. Toward a more embedded/extended perspective on the cognitive function of gestures. Front Psychol 2014; 5: 359 .

19. Nomination Database. Nobelprize.org. Nobel Media AB
2014. Web. 22 Apr 2015. http://www.nobelprize.org/ nomination/archive/show_people.php?id=6383.

20. Ansari A, Winsler A. Montessori Public School Pre-K Programs and the School Readiness of Low-Income Black and Latino Children. J Educ Psychol 2014; 106 (4): 1066-79.

21. Lillard AS. Preschool children's development in classic Montessori, supplemented Montessori, and conventional programs. J Sch Psychol 2012; 50 (3): 379-401. 